\title{
PENGARUH PENINGKATAN DERAJAT DEFORMASI CANAI HANGAT TERHADAP KARAKTERISTIK DEFORMATION BAND PADUAN Cu-Zn 70/30
}

\section{EFFECT OF INCREASING WARM ROLLING DEFORMATION DEGREE TO DEFORMATION BAND CHARACTERISTIC OF C-Zn 70/30 ALLOY}

\author{
Eka Febriyanti ${ }^{1,2, a}$, Dedi Priadi ${ }^{1, b}$, Rini Riastuti ${ }^{1, c}$ \\ ${ }^{1}$ Departemen Teknik Metalurgi dan Material, Fakultas Teknik, \\ Universitas Indonesia, Depok, Indonesia \\ ${ }^{2}$ Balai Besar Teknologi Kekuatan Struktur (B2TKS), Badan Pengkajian dan Penerapan \\ Teknologi Kekuatan Struktur (BPPT), PUSPIPTEK, Serpong, 16314, Indonesia \\ e-mail:eka.febriyanti@bppt.go.id, ${ }^{b} d e d i @ m e t a l . u i . a c . i d,{ }^{C}$ rini.riastuti@yahoo.com
}

\begin{abstract}
Abstrak
Paduan Cu-Zn 70/30 memiliki sifat yang relatif lunak, ulet, dan mudah dilakukan pengerjaan dingin. Namun, pengerjaan dingin memiliki kekurangan yaitu membutuhkan peralatan yang memiliki kapasitas pembebanan tinggi untuk menghasilkan kekuatan dan kepadatan tinggi sehingga meningkatkan biaya permesinan. Selain itu, fenomena pengerasan regang akibat proses pengerjaan dingin menghasilkan penurunan keuletan material. Oleh karena itu, diperlukan alternatif proses fabrikasi untuk mengoptimalkan sifat mekanik paduan Cu-Zn 70/30 salah satunya dengan metode TMCP. TMCP merupakan suatu proses perubahan bentuk suatu material dengan cara memberikan regangan plastis yang besar dan terkontrol terhadap material. TMCP dengan menggunakan variasi persentase deformasi sebanyak 32,25\%, 35,48\%, dan $38,70 \%$ dari penelitian canai hangat di suhu $500^{\circ} \mathrm{C}$ secara double pass reversible dilakukan pada pelat paduan Cu-Zn 70/30. Dengan melakukan pengujian tarik menggunakan mesin uji tarik universal testing machine dapat dilihat bahwa pada material paduan Cu-Zn 70/30 pada derajat deformasi 32,25\% menghasilkan nilai UTS dan YS masing-masing sebesar $505 \mathrm{MPa}$ dan $460 \mathrm{MPa}$. Sedangkan dari hasil pengamatan ketebalan dan kerapatan deformation band menggunakan FE-SEM menunjukkan deformation band yang lebih rapat dan lebih tebal sebanding dengan semakin meningkatnya derajat deformasi. Selain itu, nilai kekuatan tarik pada daerah tepi dan tengah berbanding lurus dengan kerapatan dan ketebalan deformation band.
\end{abstract}

Kata kunci : Paduan Cu-Zn 70/30, canai hangat, derajat deformasi, deformation band

\begin{abstract}
$\mathrm{Cu}-\mathrm{Zn} 70 / 30$ alloy has properties that is relatively soft, ductile, and easy to perform by cold working. However, cold working has the disadvantage that require equipment which has higher loading capacity to generate strength and higher density thus increasing of machining cost. In addition, strain hardening phenomenon due to cold working process resulted in decreasing of ductility material. Therefore, it is necessary alternative fabrication processes to optimize the mechanical properties of Cu-Zn alloy 70/30 that with the TMCP method. TMCP is metal forming material by providing large and controlled plastic strain to the material. TMCP using the deformation percentage variation that $32.25 \%, 35.48 \%$, and $38.7 \%$ from hot rolled research at $500^{\circ} \mathrm{C}$ temperature in double pass reversible which performed on $\mathrm{Cu}-\mathrm{Zn} 70 / 30$ plate. By tensile testing using universal testing machine can be seen that the Cu-Zn 70/30 alloy on 32.25\% degree of deformation, both of UTS and YS respectively are $505 \mathrm{MPa}$ and $460 \mathrm{MPa}$. Whereas from examination of thickness and density deformation bands by FE-SEM shows denser and thicker deformation band proportional with increasing of deformation degree.Moreover, the values of tensile strength at the edge of the area and the center is directly proportional to the density and thickness of the deformation band.
\end{abstract}

Key words : 70/30 Cu-Zn alloy, warm rolled, deformation degree, deformation bands 


\section{PENDAHULUAN}

Paduan Cu-Zn 70/30 memiliki sifatsifat antara lain mampu bentuk tarik dalam (deep drawing) yang tinggi, kuat, lunak, ulet, mudah dibentuk, mudah untuk dilakukan pengerjaan dingin ${ }^{(1)}$ dan memiliki ketahanan korosi atmosferik terbaik ${ }^{(2)}$ sehingga secara luas digunakan dalam banyak produk industri. Selain itu, sifat mekaniknya dapat dengan mudah ditingkatkan dengan pengerjaan dingin atau dengan solid solution alloying. Kelebihan dari proses pengerjaan dingin antara lain finishing permukaan produk lebih baik, akurasi dari dimensi produk menjadi lebih tinggi, sifat mekanik produk yang unggul seperti kekerasan dan kekuatan meningkat akibat fenomena pengerasan regangan (strain hardening phenomenon), dan adanya anisotropi material hasil pengerjaan dingin yang memberikan kemudahan ketika dilakukan proses fabrikasi tarik dalam (deep drawing). ${ }^{(3)}$

Meskipun paduan $\mathrm{Cu}-\mathrm{Zn} \quad 70 / 30$ merupakan material yang mudah dilakukan pengerjaan dingin, namun memiliki beberapa kekurangan antara lain peralatan fabrikasinya membutuhkan pembebanan yang tinggi agar menghasilkan kekuatan dan rigiditas yang tinggi sehingga dapat meningkatkan biaya permesinan. Selain itu, dengan adanya fenomena pengerasan regang (strain hardening phenomenon) dapat meningkatkan kekerasan material, bahkan material cenderung menjadi getas $^{(3)}$. Oleh karena itu, diperlukan alternatif proses fabrikasi untuk meningkatkan sifat mekanik material salah satunya dengan Thermo Mechanical Controlled Process (TMCP).

Salah satu metode TMCP yang sedang dikembangkan adalah pengerjaan canai hangat yang dapat memberikan efisiensi energi dan kemudahan pengontrolan dimensi yang lebih baik dibandingkan canai dingin ${ }^{(4)}$. Apabila dibandingkan dengan canai panas, canai hangat akan menghasilkan morfologi struktur butiran yang lebih halus dengan sifat mekanis yang lebih tinggi, kualitas permukaan dan pengendalian dimensi yang lebih baik, serta elemen yang terbuang akibat proses dekarburisasi atau oksidasi yang lebih rendah ${ }^{(5)}$.

Deformasi canai hangat dilakukan pada suhu kerja di antara canai panas dan canai dingin yang bertujuan untuk menghasilkan butiran yang halus. Suhu canai hangat berada pada range di atas suhu ruang, namun lebih rendah dibandingkan suhu rekristalisasi yaitu (0.40.6) TM (melting temperature) dimana TM untuk paduan $\mathrm{Cu}-\mathrm{Zn} 70 / 30=950^{\circ} \mathrm{C}^{(3)}$.

Berdasarkan range suhu pengerjaan canai hangat, setelah terjadi deformasi plastis, material sebagian mengalami pengerasan regangan dan sebagian mengalami rekristalisasi. Selain menghasilkan butir yang lebih halus, proses canai hangat menyebabkan material mengalami pembentukan sub-butir (subgrain) baru yang berukuran kecil pada butir yang berukuran lebih besar atau kasar. ${ }^{(6)}$

Nukleasi butir baru yang berukuran micrometer maupun sub-micrometer salah satunya terjadi pada deformation band. Deformation band merupakan cacat dalam butir mikrostruktur yang terjadi ketika material yang dideformasi di bawah temperatur rekristalisasi seperti yang terlihat pada Gambar 1. Deformation band yang terdapat didalam butir mempunyai densitas dislokasi sangat tinggi $i^{(7)}$. Densitas dislokasi yang sangat tinggi mengakibatkan dislokasi menjadi sulit bergerak sehingga material sulit dideformasi dan kekuatan tariknya meningkat ${ }^{(8)}$.

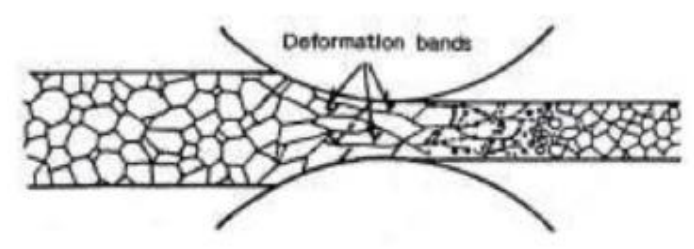

Gambar 1 : Mekanisme terbentuknya deformation band.

Dengan semakin tingginya regangan ketika proses canai hangat maka garis-garis sejajar yang disebut sebagai deformation band di permukaan butir baik pada bagian tepi maupun tengah terbentuk semakin tebal, rapat, dan struktur menyerupai lapisan. Deformation band merupakan cacat dalam butir karena kerusakan kisi-kisi kristal akibat regangan tinggi yang ditandai dengan garisgaris sejajar di permukaan butir pada pengamatan Field Emission Scanning Electron Microscope (FE-SEM) ${ }^{(9-13)}$. 
Dislokasi bergerak akibat beban yang diberikan terhadap benda uji ketika proses deformasi canai hangat sehingga menghasilkan garis-garis sejajar secara mikro yang semakin jelas terlihat pada pengamatan FE-SEM seperti yang terlihat pada Gambar 2. Garis-garis mikro tersebut merupakan cacat dalam butir akibat kerusakan kisi kristal. Deformation band yang terdapat didalam butir mempunyai densitas dislokasi sangat tinggi ${ }^{(4)}$. Densitas dislokasi yang sangat tinggi mengakibatkan dislokasi menjadi sulit bergerak sehingga dengan fenomena tersebut berdampak pada meningkatnya nilai kekuatan tarik ${ }^{(1,9)}$.

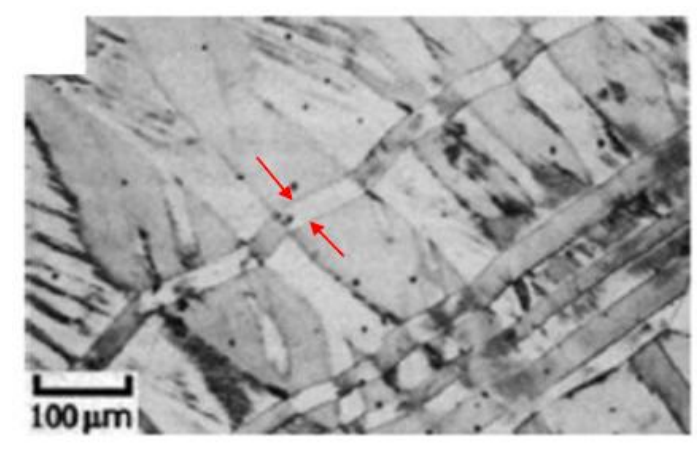

Gambar 2 : Spesimen kuningan 70/30 yang ditekan dengan persentase $12 \%$ menunjukkan adanya deformation band ${ }^{(9)}$

Tujuan dari penelitian ini adalah untuk mempelajari pengaruh peningkatan derajat deformasi terhadap karakteristik deformation band dan sifat mekanik pada pelat paduan $\mathrm{Cu}-\mathrm{Zn}$ 70/30 yang melalui proses canai hangat dengan metode double pass reversible sebanyak $32,25 \%$, $35,48 \%$ dan $38,70 \%$.

\section{BAHAN DAN METODA}

Benda uji yang digunakan adalah paduan $\mathrm{Cu}-\mathrm{Zn} \quad 70 / 30$ dengan hasil komposisi yang terlihat pada Tabel 1 .

Pengujian komposisi material paduan $\mathrm{Cu}-\mathrm{Zn} \quad 70 / 30$ dilakukan dengan menggunakan Optical Emission Spectroscopy (OES) di laboratorium.

Ukuran benda uji yang digunakan dalam penelitian ini adalah pelat berdimensi $100 \mathrm{~mm} \times 100 \mathrm{~mm} \times 3,1 \mathrm{~mm}$ seperti yang ditampilkan pada Gambar 3, lalu dihubungkan dengan kawat termokopel tipe $\mathrm{K}$ berdiameter $2 \mathrm{~mm}$.

Tabel 1. Komposisi benda uji paduan $\mathrm{Cu}$ $\mathrm{Zn} 70 / 30$

\begin{tabular}{ccc}
\hline Unsur & $\begin{array}{c}\text { Penelitian } \\
\text { (wt\%) }\end{array}$ & $\begin{array}{c}\text { Target* }^{*} \\
\text { (wt\%) }\end{array}$ \\
\hline $\mathrm{Cu}$ & 69,5 & $69,5-72$ \\
\hline $\mathrm{Zn}$ & 30,7 & sisa \\
\hline $\mathrm{Fe}$ & 0,026 & $\sim \max .0,05$ \\
\hline $\mathrm{Sn}$ & 0,0062 & $\sim \max .0,03$ \\
\hline $\mathrm{Al}$ & $<0,002$ & $\sim \max .0,03$ \\
\hline $\mathrm{Ni}$ & - & $\sim \max .0,2$ \\
\hline $\mathrm{As}$ & $<0,001$ & $\sim \max .0,02$ \\
\hline $\mathrm{Pb}$ & $<0,005$ & $\sim \max .0,05$ \\
\hline $\mathrm{Si}$ & $<0,005$ & $\sim \max .0,01$ \\
\hline $\mathrm{Mn}$ & 0,0052 & $\sim \max .0,04$ \\
\hline $\mathrm{P}$ & $<0,003$ & $\sim \max .0,05$ \\
\hline $\mathrm{Sb}$ & - & $\sim \max .0,01$ \\
\hline $\mathrm{Bi}$ & - & $\sim \max .0,04$ \\
\hline${ }^{*}$ Target $:$ standard $P I N D A D$
\end{tabular}

Pengukuran temperatur menggunakan data acquisition system yang dihubungkan dengan perangkat komputer.

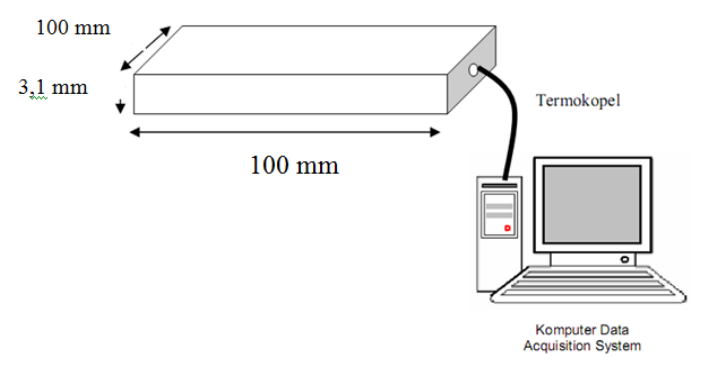

Gambar 3 : Rangkaian pengujian canai hangat

Proses deformasi canai hangat didahului dengan pemanasan sampel pada dapur karbolit dengan temperature $700^{\circ} \mathrm{C}$ selama 90 menit, yang kemudian dilanjutkan proses canai pada mesin On Roll kapasitas 20 tonF dengan parameter deformasi canai double pass reverse, secara bolak-balik sebanyak 32,25\%, $35,48 \%$, dan $38,70 \%$ yang dilanjutkan dengan pendinginan udara.

Penelitian ini diawali dengan pemanasan awal benda uji dari suhu ruang ke suhu $700^{\circ} \mathrm{C}$ selama 30 menit lalu ditahan selama 90 menit untuk proses homogenisasi yang bertujuan untuk 
menghasilkan ukuran butir yang lebih seragam, kemudian dilanjutkan dengan pendinginan dalam oven ke suhu ruang seperti yang terlihat pada Gambar 4.

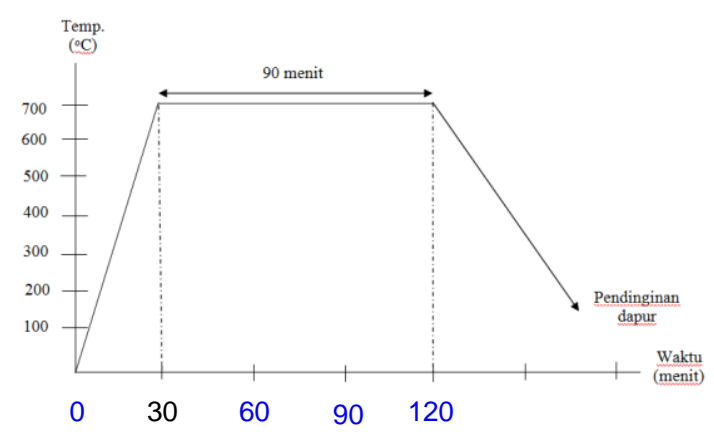

Gambar 4 : Diagram tahapan homogenisasi di temperatur $700^{\circ} \mathrm{C}$ selama 90 menit

Selanjutnya dilakukan pemanasan ke suhu $500^{\circ} \mathrm{C}$ dengan waktu 15 menit dan ditahan selama 15 menit lalu dilakukan canai hangat secara double pass reversible dengan derajat deformasi 32,25\%, 35,48\%, dan $38,70 \%$ kemudian dilanjutkan dengan pendinginan di udara, tahapan proses ditunjukkan pada Gambar 5.

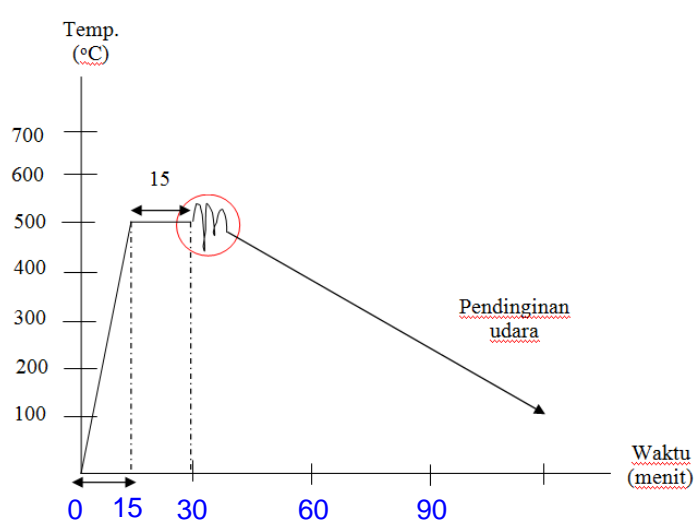

Gambar 5 : Diagram tahapan canai hangat pada temperatur $500^{\circ} \mathrm{C}$ dengan metode double pass reversible

Proses canai hangat dilanjutkan dengan pengujian tarik. Pengujian tarik dilakukan untuk mengetahui kekuatan tarik dan nilai keuletan. Sampel uji tarik mengacu pada standard ASTM E8 ${ }^{(14)}$ dengan menggunakan mesin uji tarik Servopulser Shimadzu dan peralatan tambahan seperti jangka sorong dial indicator, dan perlengkapannya.

Sedangkan benda uji untuk pengujian tarik seperti yang terlihat pada Gambar 6.

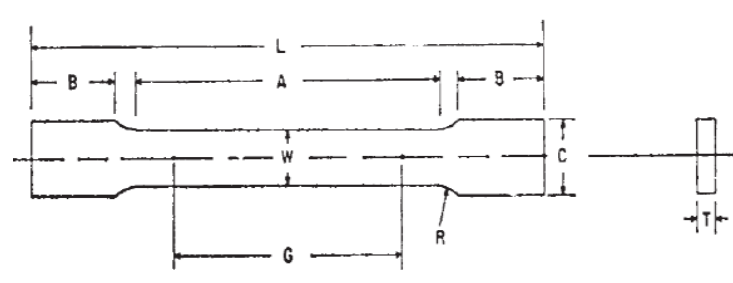

Keterangan :

$\mathrm{L}=$ minimal $100 \mathrm{~mm}$,

$\mathrm{G}=25 \mathrm{~mm}, \mathrm{C}=10 \mathrm{~mm}$

Gambar 6 : Sampel uji tarik

Untuk menghitung nilai UTS (ultimate tensile strength), YS (yield strength), dan $\varepsilon$ (elongasi) dari material paduan $\mathrm{Cu}-\mathrm{Zn}$ 70/30 menggunakan persamaan sebagai berikut :

$$
\begin{gathered}
\sigma U T S=F \max \div \text { Ao } \\
\varepsilon=(\operatorname{lmax}-l o) \div l o
\end{gathered}
$$

Setelah dilakukan pengujian tarik selanjutnya dilakukan pengamatan FE-SEM (Field Emission-Scanning Electron Microscope). Pengamatan FE-SEM bertujuan untuk mengamati tekstur permukaan butir seperti deformation band dan distribusinya. Pengamatan FE-SEM dilakukan dengan perbesaran $1000 \mathrm{X}, 2000$ X, 5000 X, 10000 X, dan 20000 X. Sebelum dilakukan pengamatan FE-SEM maka diperlukan preparasi benda uji berdasarkan standard ASTM E3-01 ${ }^{(15)}$.

Persiapan benda uji sebelum pengamatan FE-SEM meliputi pencetakan sampel, pengamplasan, dan pemolesan sampel sampai mendapatkan permukaan yang lebih halus dan mengkilap serta bebas goresan akibat pengamplasan. Proses selanjutnya yaitu etsa yang bertujuan untuk memunculkan tekstur permukaan butir seperti deformation band pada benda uji dengan menggunakan zat etsa ferric klorida atau $10 \% \mathrm{FeCl}_{3}$ yang terdiri atas $10 \mathrm{gr} \mathrm{FeCl}_{3}$ dan $90 \mathrm{ml}$ alcohol 96\%. Kemudian dilakukan pengamatan deformation band dan distribusinya menggunakan FE-SEM. 


\section{HASIL DAN PEMBAHASAN}

Peningkatan nilai kekuatan tarik (MPa) baik UTS maupun YS dan kekerasan (HV) seperti yang terlihat pada Tabel 2 berhubungan dengan terhambatnya pergerakan dislokasi di dalam material.

Tabel 2. Data hasil uji tarik paduan $\mathrm{Cu}-\mathrm{Zn}$ $70 / 30$ setelah diproses canai hangat ${ }^{(16)}$

\begin{tabular}{cccc}
\hline $\begin{array}{c}\text { Derajat } \\
\text { Deformasi } \\
(\%)\end{array}$ & $\begin{array}{c}\text { UTS } \\
(\mathrm{MPa})\end{array}$ & $\begin{array}{c}\mathrm{YS}^{(1 /)} \\
(\mathrm{MPa})\end{array}$ & $\varepsilon(\%)$ \\
\hline- & 308,58 & 174,53 & 68 \\
\hline 32,25 & 505,18 & 402,04 & 21 \\
\hline 35,48 & 502,29 & 437,50 & 6 \\
\hline 38,70 & 533,05 & 435,26 & 10 \\
\hline
\end{tabular}
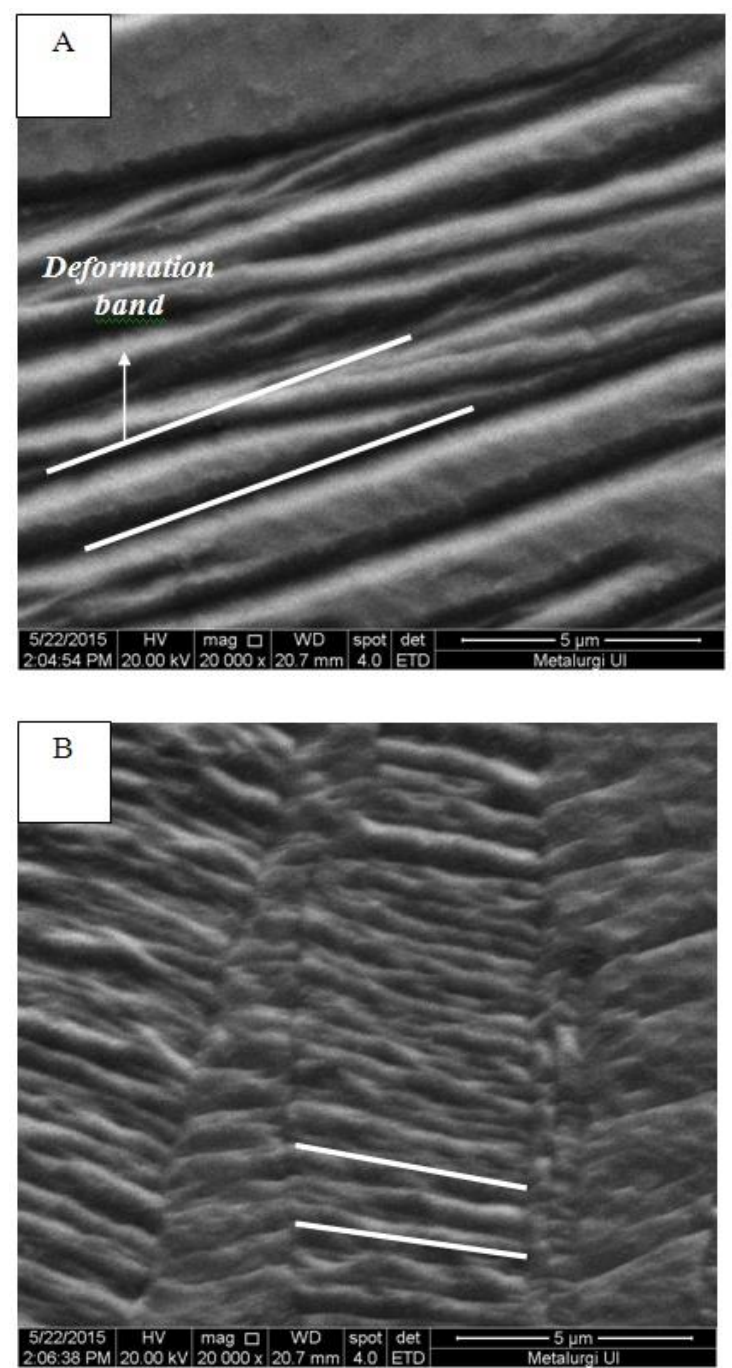
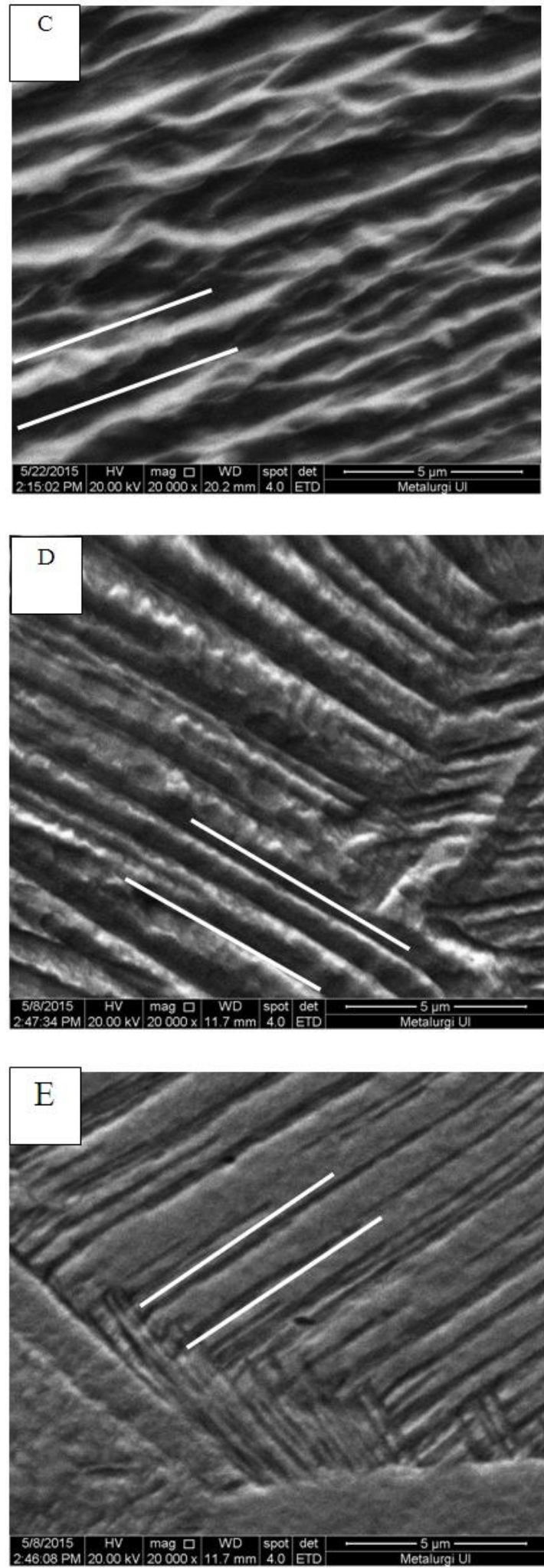

Gambar 7a : Pengamatan deformation band dari FE-SEM untuk benda uji canai hangat, deformasi 32,25\% (A) Bagian tepi, (B) Bagian tengah; deformasi 35,48\% (C) Bagian tepi, (D) Bagian tengah; deformasi 38,70\% (E) Bagian tepi, (F) Bagian tengah. 


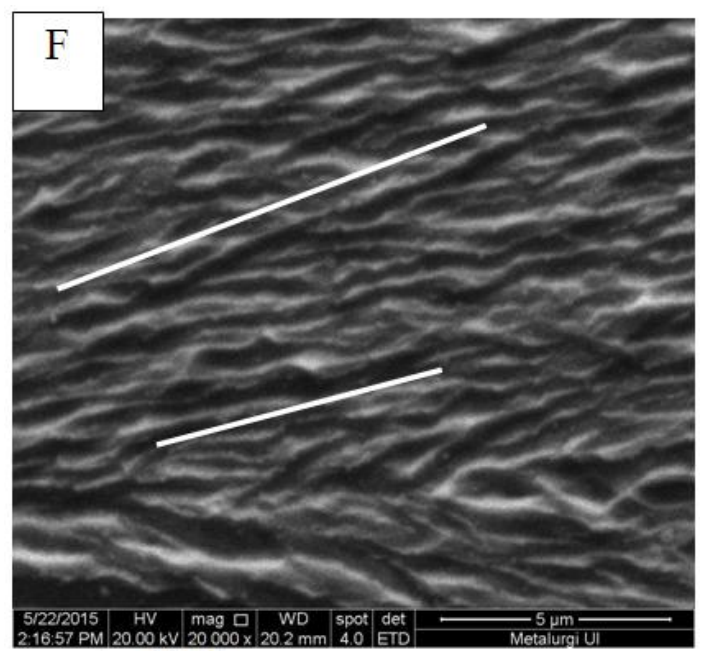

Gambar 7b : Pengamatan deformation band dari FE-SEM untuk benda uji canai hangat, deformasi 32,25\% (F) Bagian tengah.

Sulitnya pergerakan dislokasi disebabkan karena densitas dislokasi yang sangat tinggi $i^{(7-9)}$. Densitas dislokasi yang tinggi biasanya terdapat pada deformation band di dalam butir. Deformation band merupakan cacat dalam butir berupa garis-garis mikro akibat kerusakan kisi kristal ${ }^{(9)}$. Oleh karena itu, deformation band hanya terlihat dengan pengamatan FE-SEM minimal 1000X seperti yang terlihat pada Gambar 7a \& 7b.

Dengan semakin meningkatnya derajat deformasi (\%) maka deformation band yang terbentuk semakin banyak, yang artinya densitas dislokasi yang terdapat dalam deformation band semakin meningkat. Peningkatan densitas dislokasi secara makroskopik dibuktikan dengan penurunan jarak antar deformation band atau dapat disebut jarak antar deformation band yang satu dengan lainnya semakin rapat yang terjadi pada derajat deformasi (\%) yang lebih tinggi seperti yang terlihat pada Tabel 3 dan Gambar 8. Selain itu, morfologi ketebalan deformation band yang terbentuk semakin lebar yang ditandai dengan semakin menebalnya deformation band pada derajat deformasi (\%) yang lebih tinggi seperti yang terlihat pada Tabel 4 dan Gambar 9.

Namun di antara bagian tepi dan bagian tengah, bagian tepi memiliki kerapatan dan ketebalan deformation band yang lebih rapat dan lebih tebal karena bagian tepi mengalami deformasi yang 14 lebih besar dibandingkan bagian tengah ketika proses canai hangat.

Tabel 3. Data kerapatan deformation band paduan $\mathrm{Cu}-\mathrm{Zn}$ 70/30 setelah diproses canai hangat

\begin{tabular}{ccc}
\hline $\begin{array}{c}\text { Derajat } \\
\text { Deformasi } \\
(\%)\end{array}$ & $\begin{array}{c}\text { Kerapatan } \\
\text { Tepi } \\
(\mu \mathrm{m})\end{array}$ & $\begin{array}{c}\text { Kerapatan } \\
\text { Tengah } \\
(\mu \mathrm{m})\end{array}$ \\
\hline 32,25 & 0,46 & 0,46 \\
\hline 35,48 & 0,33 & 0,37 \\
\hline 38,70 & 0,30 & 0,36 \\
\hline
\end{tabular}

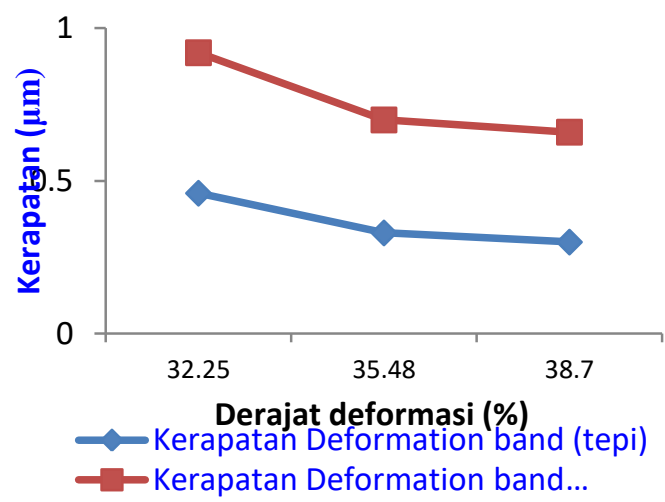

Gambar 8 : Hubungan antara derajat deformasi (\%) dengan kerapatan deformation band $(\mu \mathrm{m})$.

Tabel 4. Data ketebalan deformation band paduan $\mathrm{Cu}-\mathrm{Zn}$ 70/30 setelah diproses canai hangat

\begin{tabular}{ccc}
\hline $\begin{array}{c}\text { Derajat } \\
\text { Deformasi } \\
(\%)\end{array}$ & $\begin{array}{c}\text { Ketebalan } \\
\text { Tepi } \\
(\mu \mathrm{m})\end{array}$ & $\begin{array}{c}\text { Ketebalan } \\
\text { Tengah } \\
(\mu \mathrm{m})\end{array}$ \\
\hline 32,25 & 0,86 & 0,55 \\
\hline 35,48 & 1,1 & 0,57 \\
\hline 38,7 & 1,51 & 0,89 \\
\hline
\end{tabular}

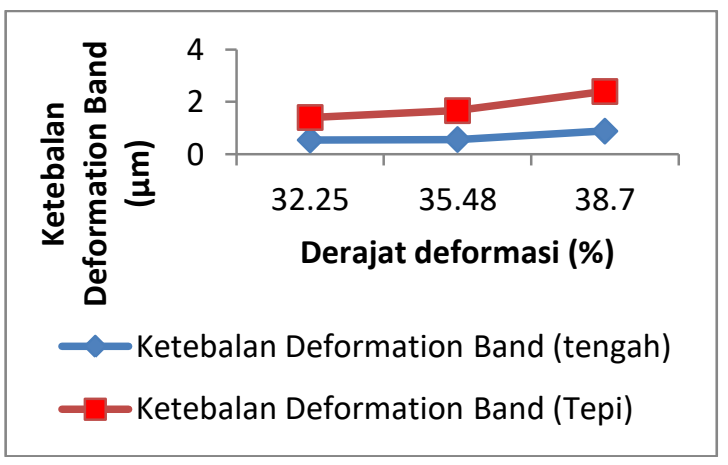

Gambar 9 : Hubungan antara derajat deformasi (\%) dengan ketebalan deformation band $(\mu \mathrm{m})$ 


\section{KESIMPULAN DAN SARAN}

Nilai kerapatan deformation band maksimum baik pada bagian tepi maupun tengah diperoleh pada derajat deformasi mencapai $38,70 \%$. Selain itu, nilai ketebalan deformation band juga menunjukkan nilai maksimum ketika derajat deformasi mencapai 38,70\% baik di bagian tepi maupun di bagian tengah sampel.

Jadi, dengan semakin tinggi derajat deformasi maka deformation band semakin rapat. Selain itu, dengan semakin tinggi derajat deformasi maka deformation band semakin tebal.

UTS maksimum tercapai ketika proses TMCP dilakukan pada derajat deformasi $38,70 \%$. Untuk YS maksimum tercapai ketika proses TMCP dilakukan pada derajat deformasi $35,48 \%$. Sedangkan nilai \% elongasi maksimum tercapai ketika proses TMCP dilakukan pada derajat deformasi $32,25 \%$.

Sedangkan saran untuk penelitian selanjutnya yaitu dapat dicoba dengan canai hangat pada derajat deformasi lebih besar atau sama dengan $50 \%$. Selain itu, untuk pendalaman observasi disarankan untuk menggunakan alat XRD (X-Ray Diffractometer) dan TEM (Transmission Electron Microscope).

\section{UCAPAN TERIMA KASIH}

Penulis mengucapkan terima kasih kepada Kemenristekdikti yang memberikan beasiswa sehingga penulis dapat melanjutkan pendidikan S2 DTMM FTUI dan melakukan penelitian. Ucapan terima kasih juga kepada Dr. Barman Tambunan selaku Kepala B2TKS BPPT, Dr. Sri Harjanto selaku Kepala Jurusan DTMM FTUI, dan Dr.Ing.H.Agus Suhartono selaku Kepala Bidang Kajian Material B2TKS, untuk koordinasi dan pemberian ijin dalam menggunakan alat uji laboratorium.

\section{DAFTAR PUSTAKA}

1. William D.Callister Jr. An Introduction : Material Science and Engineering. John Wiley \& Son, Inc. hal.373.2007

2. A.La Fontaine, V.J.Keast. "Compositional Distributions in Classiscal and Lead-free Brasses." Material Characterization. (2006) hal.424-429

3. Altan T. Oh S. and Gegel H. Metal Forming Fundamentals and Applications : Plastic Deformation of Metals and Related Properties. American Soc. for Metals. Metal Park. OH. 2012

4. Yajima et al.,"Extensive Application of TMCP-manufactured High Tensile Steel Plates to Ship Hulls and Offshore Structures." Mitsubishi Heavy Industries Technical Review Vol 24 No. 1 (1987)

5. Y. Adachi, M. Wakita, H. Beladi, P. D. Hodgson, "The Formation of Ultrafine Ferrite Through Static Transformation in Low Carbon Steels." Journal Acta Materialia. Elsevier. Vol. 55 (2007) hal.4925-2934

6. S. Dobatkin, J. Zrnik. "UltrafineGrained Low Carbon Steels by Severe Plastic Deformation." Journal Metalurgija. Vol. 47. (2008) hal.181186

7. Beladi, Hossein et al. "The Effect of Multiple Deformations on the Formation of Ultrafine Grained Steel." Metallurgical and Materials Trans. Vol.38A (2007) hal.450-155

8. R. E. Smallman, R. J. Bishop. Modern Physical Metallurgy and Materials Engineering. ButterworthHeinemann. Vol. 6. 1999.

9. F. J. Humphreys dan M.Hatherly. Recrystallization and Related Annealing Phenomena." Pergamon Press. 2004

10. Svetlana Nestorovic, Desimir Markovic, dan Ljubica Ivanic. "Influence Of Degree Of Deformation In Rolling On Anneal Hardening Effect Of A Cast Copper Alloy." Bulletin Material Science.Vol. 26. No. 6. (2003) hal. 601-604.

11. C. Zheng, N. Xiao. "Microstructure Prediction of The Austenite Recrystallization During Multi-Pass Steel Strip Hot Rolling." Computational Materials Science. Vol. 44 (2008) hal. 507-514.

12. Verlinden, Berth, Julian Driver, Indradev Samadjar \& Roger D.Doherty. Thermo-Mechanical Processed of Metallic Materials. Elsevier. Ltd.2007

13. Charlie R.Brooks. Heat Treatment, Structure and Properties of NonFerrous Alloys. ASM International. 1986 
M.I. Mat. Konst. Vol. 16 - Juni 2016 - Hal 9-16

14. ASTM E8. Standard Test Methods for Tension Testing of Metallic Materials. 2003

15. ASTM E3. Standard Guide for Preparation for Metallographic Specimens. 2003

16. Febriyanti, Eka, Dedi Priadi, dan Rini Riastuti. "Pengaruh Thermo Mechanical Controlled Processed (TMCP) terhadap Penghalusan Butir dan Sifat Mekanik Paduan Cu-Zn 70/30." Majalah Metalurgi. Vol.30. No.3 (2015) hal. 141-148

17. Krishna Chenna, S., et.al., "On the Prediction of Strength from Hardness for Copper Alloys." Journal of Materials. article ID 352578. Hindawi Publishing Corporation. (2013) hal.16 
Pengaruh Peningkatan Derajat Deformasi Canai - Eka Febriyanti, Dedi Priadi, Rini Riastuti 